\title{
Complete mitochondrial genome of the California halibut, Paralichthys californicus
}

\section{Genoma mitocondrial completo del lenguado de California, Paralichthys californicus}

\author{
Carmen E Vargas-Peralta, Claudia Farfán, Fabiola Lafarga-De La Cruz, Benjamín Barón-Sevilla, \\ Miguel A Del Río-Portilla* \\ Departamento de Acuicultura, Centro de Investigación Científica y de Educación Superior de Ensenada, \\ Carretera Ensenada-Tijuana, No. 3918, Zona Playitas, CP 22860, Ensenada, Baja California, Mexico. \\ * Corresponding author. Email: mdelrio@cicese.mx
}

\begin{abstract}
The California halibut, Paralichthys californicus, is a highly priced flatfish because of its size and meat quality. This work presents the complete mitochondrial genome of $P$. californicus. Total DNA from muscle tissue was extracted and sequenced using the Illumina platform. Reads were cleaned, trimmed, assembled de novo, and annotated. The California halibut mitogenome is 16,858 bp in length (GenBank accession number: MT859134), containing 13 protein-coding genes, 22 tRNAs, 2 rRNAs, and the control region. P. californicus mitogenome was most similar to Paralichthys olivaceus than to other flatfish mitogenomes, in agreement with their geographic distribution. This information deepens the knowledge of the California halibut, which is not only ecologically important, but also a socioeconomically relevant resource for fishery and aquaculture in California, USA, and Baja California, Mexico.
\end{abstract}

Key words: mitogenome, next-generation sequencing (NGS), mass sequencing, California halibut, Paralichthys californicus.

RESUMEN. El lenguado de California, Paralichthys californicus, es una especie de pez plano con un alto valor econónico debido a su tamaño y a la calidad de su carne. En este trabajo se presenta el genoma mitocondrial completo de P. californicus. Se extrajo ADN total de tejido muscular y se secuenció utilizando la plataforma Illumina. Las lecturas obtenidas se limpiaron, se recortaron, se ensamblaron de novo y se anotaron. El mitogenoma del lenguado de California tiene una logitud de 16,858 pb (número de acceso del GenBank: MT859134) y contiene 13 genes codificadores de proteínas, $22 \mathrm{ARNt}, 2 \mathrm{ARNr}$ y la región control. El mitogenoma de P. californicus fue más similar al de Paralichthys olivaceus que a mitogenomas de otros peces planos, en concordancia con su distribución geográfica. La información aquí presentada incrementa el conocimiento del lenguado de California, el cual no solo es una especie de importancia económica, sino también un recurso socioeconómico relevante para la pesquería y la acuicultura de California, EUA, y de Baja California, México.

Palabras clave: mitogenoma, secuenciación de siguiente generación (NGS), secuenciación masiva, lenguado de California, Paralichthys californicus.

\section{INTRODUCTION}

The California halibut, Paralichthys californicus Ayres, 1859, is an important benthic aquatic resource of shallow nearshore areas and bays of California, USA, and Baja California, Mexico (Gracian-Negrete et al. 2015). The distribution of P. californicus ranges from northern Washington State, USA, to southern Baja California, Mexico, along the Pacific coast and into the Gulf of California. This flatfish is highly priced for domestic and export markets, mainly in Asia. It reaches over $1.5 \mathrm{~m}$ in total length and can weigh more than $30 \mathrm{~kg}$ (Gracian-Negrete et al. 2015). Paralichthys californicus stands out in the domestic and export markets for its high-quality meat for human consumption. In Mexico, official catch numbers comprise 11 different species, all of them considered to be part of a single flatfish fishery (Gracian-Negrete et al. 2015, SEPESCABC 2017). In the state of Baja California, the flatfish fishery is considered within the finfish category, which ranks sixth

\section{INTRODUCCIÓN}

El lenguado de California, Paralichthys californicus Ayres, 1859, es un importante recurso acuático bentónico de áreas poco profundas cercanas a la costa y bahías de California, EUA, y Baja California, México (Gracian-Negrete et al. 2015). La distribución de P. californicus va desde el norte del estado de Washington, EUA, hasta el sur de Baja California, México, a lo largo de la costa del Pacífico y en el golfo de California. Este pez plano es altamente cotizado en los mercados nacionales y de exportación, principalmente en Asia. Alcanza más de $1.5 \mathrm{~m}$ de longitud total y puede pesar más de $30 \mathrm{~kg}$ (Gracian-Negrete et al. 2015). Paralichthys californicus destaca en el mercado nacional y de exportación por su carne de alta calidad para consumo humano. En México, las cifras de captura oficiales abarcan 11 especies diferentes, todas consideradas como parte de una sola pesquería de peces planos (Gracian-Negrete et al. 2015, SEPESCABC 2017). En el estado de Baja California, la 
in terms of average annual production value (SEPESCABC 2017), and the production of this multispecies fishery increased in Mexico from $325 \mathrm{t}$ in 2011 to $577 \mathrm{t}$ in 2018. In 2018 , the value of this commercial and recreational fishery was 1.4 million USD, reaching the highest average price of 2.5 USD per kilogram. Compared to 2017, its average price per kilogram increased up to $159 \%$. There is only one Mexican fishery report for P. californicus (Gracian-Negrete et al. 2015), which states that 2,400 t were captured in Bahía de los Ángeles in 1990. However, this place has been listed as a biosphere reserve since 2007 (DOF 2007, 2010), and the fishery has declined. Additionally, an $80 \%$ reduction in the flatfish fishery in subsequent years has been reported (Gracian-Negrete et al. 2015), which is consistent with reports for recent years.

On the other hand, there is a high market demand for halibut in Asia. The United Nations Food and Agriculture Organization (FAO) reported a catch of 10,665 t of Japanese halibut, Paralichthys olivaceus (a species that attains a standard length of $80 \mathrm{~cm}$ ), in 2016, mainly by Japan and the Republic of Korea (FAO 2020). Fishing of this species has dropped; by contrast, aquaculture production is on the rise, as shown by official aquaculture statistics, from 1,572 $\mathrm{t}$ in 1985 to $43,929 \mathrm{t}$ in 2016 (FAO 2020). This indicates that flatfish aquaculture is very important worldwide, and P. californicus farming might be lucrative for the Mexican economy. It is therefore essential to describe the ecological and genetic aspects of Mexican populations of the California halibut, P. californicus, to inform its culture and provide genetic tools to develop fishery and aquaculture management strategies. Furthermore, genetic data on flatfish species are also important elements in studies on the evolution of novel body plans.

Nuclear and mitochondrial genetic markers have been used to characterize species of economic importance. About 2 decades ago, the genetic characterization of a species of interest frequently required knowing its DNA sequences. Nowadays, next-generation sequencing (NGS) has allowed the development of novel genetic analyses with no previous knowledge of the DNA sequences for a particular species, and its impact has been recognized for more than a decade (Schuster 2008, Metzker 2010, Chinmayee et al. 2018). Mitochondrial genomes have been obtained by NGS using Illumina platforms for marine (Del Río-Portilla et al. 2016c, Galván-Tirado et al. 2016, León-Pech et al. 2016) and freshwater fishes (Barriga-Sosa et al. 2016; Camarena-Rosales et al. 2016; Del Río-Portilla et al. 2016a, b), elasmobranchs (Castillo-Páez et al. 2016a, b), corals (Del Río-Portilla et al. 2016d), and mollusks (Bisbal-Pardo et al. 2016a, b; Magallón-Gayón et al. 2020).

This work presents the complete mitochondrial genome of $P$. californicus as new genetic information to build baseline molecular data for this species. pesquería de peces planos se considera dentro de la categoría de peces de aleta, que ocupa el sexto lugar en términos de valor de producción anual promedio (SEPESCABC 2017), y la producción de esta pesquería multiespecífica aumentó en México de 325 t en 2011 a 577 t en 2018. En 2018, el valor de esta pesquería comercial y recreativa fue de 1.4 millones de dólares, con lo que alcanzó el precio promedio más alto de 2.5 dólares por kilogramo. En comparación con 2017, el precio promedio por kilogramo aumentó hasta en un $159 \%$. Solo hay un informe pesquero mexicano de $P$. californicus (Gracian-Negrete et al. 2015), el cual indica que en 1990 se capturaron 2,400 t en bahía de los Ángeles. Sin embargo, este lugar ha estado catalogado como reserva de la biósfera desde 2007 (DOF 2007, 2010), y la pesquería ha disminuido. Además, se ha informado de una reducción del $80 \%$ en la pesquería de peces planos en los años posteriores (Gracian-Negrete et al. 2015), lo que es congruente con los informes de los últimos años.

Por otro lado, la demanda de lenguado en Asia es alta. La Organización de las Naciones Unidas para la Agricultura y la Alimentación (FAO, por sus siglas en inglés) reportó una captura de 10,665 t de lenguado japonés, Paralichthys olivaceus (una especie que alcanza una longitud estándar de $80 \mathrm{~cm}$ ), en 2016, principalmente por Japón y la República de Corea (FAO 2020). La pesca de esta especie ha disminuido; por el contrario, la producción acuícola va en aumento, como lo muestran las estadísticas oficiales de acuicultura, de 1,572 t en 1985 a 43,929 t en 2016 (FAO 2020). Ello indica que la acuicultura de peces planos es muy importante a nivel mundial, y el cultivo de P. californicus podría ser lucrativo para la economía mexicana. Por lo tanto, es esencial describir los aspectos ecológicos y genéticos de las poblaciones mexicanas del lenguado de California, P. californicus, para informar sobre su cultivo y proporcionar herramientas genéticas para desarrollar estrategias de manejo pesqueras y de cultivo. Además, los datos genéticos sobre especies de peces planos también son elementos importantes en los estudios sobre la evolución de nuevos planes corporales.

Se han utilizado marcadores genéticos nucleares y mitocondriales para caracterizar especies de importancia económica. Hace aproximadamente 2 décadas, la caracterización genética de una especie de interés frecuentemente requería conocer sus secuencias de ADN. Hoy en día, la secuenciación de nueva generación (NGS, por sus siglas en inglés) ha permitido el desarrollo de nuevos análisis genéticos sin necesidad de conocimiento previo de las secuencias de ADN para una especie en particular, y su impacto ha sido reconocido durante más de una década (Schuster 2008, Metzker 2010, Chinmayee et al. 2018). Se han obtenido genomas mitocondriales mediante la NGS utilizando plataformas Illumina para peces marinos (Del Río-Portilla et al. 2016c, Galván-Tirado et al. 2016, León-Pech et al. 2016) y peces de agua dulce (Barriga-Sosa et al. 2016; Camarena-Rosales et al. 2016; Del Río-Portilla et al. 2016a, b), elasmobranquios (Castillo-Páez 
Vargas-Peralta et al.: Mitogenome of Paralichthys californicus

\section{MATERIALS AND METHODS}

A muscle sample from a California halibut was collected for the analysis. One fish was caught in Ejido Eréndira, Baja California, Mexico (31 $\left.15^{\prime} 41^{\prime \prime} \mathrm{N}, 116^{\circ} 22^{\prime} 52^{\prime \prime} \mathrm{W}\right)$, as broodstock and kept in captivity at CICESE (Centro de Investigación Científica y de Educación Superior de Ensenada, Baja California) prior to sampling. The specimen analyzed was handled in accordance with the ethical standards for the use of fish in research of the American Fisheries Society; all applicable institutional guidelines for animal care were followed. Total DNA was extracted using the QIAGEN DNeasy Blood \& Tissue kit. A high-quality DNA sample was sent to the Georgia Genomics Facility (University of Georgia; Athens, GA) for NGS. DNA was sheared by sonication with Bioruptor using 2 rounds, each consisting of 5 cycles of 30 -s sonicating (high setting) plus $30 \mathrm{~s}$ with no sonication. The library prep protocol was followed using the Kapa Biosystems Hyper Prep Kit (KR0961-v4.15), ligating custom adapter stubs and amplification through 12 PCR cycles with custom nucleotide indexed primers (Glenn et al. 2019). Dual-size selection with magnetic beads (Speed Beads, Rohland and Reich 2012) was performed to recover fragment sizes of $\sim 250-450$ bp. Libraries were sequenced in Illumina MiSeq to produce $300 \mathrm{bp}$ paired-end reads.

Reads from fastq files were cleaned by trimming lowquality regions (quality limit $=0.05$ ) followed by de-novo assembling with the CLC Genomics Workbench 6.5 software, using the following settings: bubble size (248) and word size (22), minimum contig length (200 bp), perform scaffolding (yes), and auto-detect paired distances.

Contigs were filtered to provide a coverage $\geq 1.5$ and more than 3 reads per contig after mapping reads to contigs. The longest contig identity was blasted to the nucleotide NCBI (National Center for Biotechnology Information, https:// www.ncbi.nlm.nih.gov) database using the Basic Local Alignment Search Tool (Blast) (Camacho et al. 2009). Once identified, the mitochondrial genome was annotated with the Dual Organellar GenoMe Annotator, DOGMA (Wyman et al. 2004), MITOS (Bernt et al. 2013), and MitoFish (Iwasaki et al. 2013) web programs using the respective default settings. Protein translation was verified with ExPASy (http:// www.expasy.org) (Artimo et al. 2012) and tRNA was confirmed with tRNAscan (Lowe and Eddy 1997) and by comparison with other tRNA. The phylogenetic analysis was performed by comparison against complete mitogenomes of other flatfish from the NCBI GenBank site (Table 1). The MEGA software (Kumar et al. 2016) was used for mitogenome alignment using the ClustalW (Thompson et al. 1994) procedure with default settings. jModelTest 2 software (Guindon and Gascuel 2003, Darriba et al. 2012) was used to select the best-fit nucleotide substitution model using Akaike (AIC) and Bayesian (BIC) information criteria with default settings. MrBayes 3.2 (Ronquist and Huelsenbeck 2003) was used to estimate the phylogenetic relationships with the et al. 2016a, b), corales (Del Río-Portilla et al. 2016d) y moluscos (Bisbal-Pardo et al. 2016a, b; Magallón-Gayón et al. 2020).

Este trabajo presenta el genoma mitocondrial completo de P. californicus como nueva información genética para construir datos moleculares de referencia para esta especie.

\section{MATERIALES Y MÉTODOS}

Se obtuvo una muestra de músculo de un lenguado de California para el análisis. Un pez fue capturado en Ejido Eréndira, Baja California, México ( $31^{\circ} 15^{\prime} 41^{\prime \prime} \mathrm{N}, 116^{\circ} 22^{\prime} 52^{\prime \prime}$ $\mathrm{W})$, como reproductor y se mantuvo en cautiverio en el CICESE (Centro de Investigación Científica y de Educación Superior de Ensenada, Baja California) antes del muestreo. El espécimen analizado se manipuló de acuerdo con las normas éticas de la American Fisheries Society para el uso de peces en la investigación. Se siguieron todas las pautas institucionales aplicables para el cuidado de los animales. El ADN total se extrajo utilizando el kit QIAGEN DNeasy Blood \& Tissue. Se envió una muestra de ADN de alta calidad a Georgia Genomics Facility (Universidad de Georgia; Athens, Georgia) para la NGS. El ADN se cortó mediante sonicación con Bioruptor utilizando 2 rondas, cada una de las cuales constó de 5 ciclos de sonicación de $30 \mathrm{~s}$ (modo alto) más $30 \mathrm{~s}$ sin sonicación. El protocolo de preparación de la biblioteca se siguió utilizando el kit Kapa Biosystems Hyper Prep (KR0961-v4.15), y se ligaron los adaptadores personalizados y la amplificación a través de 12 ciclos de PCR con cebadores indexados de nucleótidos personalizados (Glenn et al. 2019). Se realizó una selección de tamaño dual con perlas magnéticas (Speed Beads, Rohland y Reich 2012) para recuperar tamaños de fragmentos de $\sim 250-450 \mathrm{pb}$. Las bibliotecas se secuenciaron en Illumina MiSeq para producir lecturas pareadas de $300 \mathrm{pb}$.

Las lecturas de los archivos fastq se limpiaron recortando las regiones de baja calidad (límite de calidad $=0.05$ ), seguido de un ensamblaje de novo con el programa CLC Genomics Workbench 6.5. Se utilizaron las siguientes configuraciones: tamaño de burbuja (248) y tamaño de palabra (22), longitud mínima de cóntigos (200 pb), ensamblaje en andamios (sí) y detección automática de distancias emparejadas.

Los cóntigos se filtraron para proporcionar una cobertura $\geq 1.5$ y más de 3 lecturas por cóntigo después de la asignación de lecturas a cóntigos. La identidad de cóntigo más larga se envió a la base de datos de nucleótidos del NCBI (Centro Nacional de Información Biotecnológica, https:// www.ncbi.nlm.nih.gov) utilizando la Herramienta Básica de Búsqueda de Alineación Local (Blast, por sus siglas en inglés) (Camacho et al. 2009). Una vez identificado, el genoma mitocondrial se anotó con los programas web Dual Organellar GenoMe Annotator, DOGMA (Wyman et al. 2004), MITOS (Bernt et al. 2013) y MitoFish (Iwasaki et al. 2013) mediante la configuración predeterminada respectiva. La traducción a proteínas se verificó con ExPASy 
best-fit model: the General Time Reversible (GTR) model of evolution with a gamma-distribution substitution model and a gamma-distributed rate variation across sites $(\mathrm{GTR}+\mathrm{G}+\mathrm{I})$, running the Markov chain Monte Carlo simulation with 20,000 generations, 100 sample frequencies, and default settings. The phylogenetic tree was built using FigTree V1.4.4 (Rambaut 2018). FishBase (Froese and Pauly 2019) and WoRMS (WoRMS Editorial Board 2020) databases were reviewed to obtain the number of Paralichthys species and their geographic distribution.

\section{RESULTS AND DISCUSSION}

After trimming the low-quality regions and eliminating failed reads, the remaining total number of reads was $3,243,808$. A total of 284,243 contigs were assembled with a maximum of $16,858 \mathrm{bp}$ and a minimum of $200 \mathrm{bp}$. The largest contig (16,858 bp, 35.82x coverage; GenBank accession number: MT859134) matched the mitogenome of the California halibut, which contains 13 protein-coding genes, 22 tRNAs, and 2 rRNAs (Table 2). Also found was a putative control region (D-loop) of 1,168 bp as suggested by the MitoFish server and it was also present in other flatfishes (Fig. 1, Table 2). The mitogenome nucleotide frequencies observed in P. californicus were $27.5 \%$ adenine (A), $29.5 \%$ cytosine (C), $17.0 \%$ guanine $(\mathrm{G})$, and $26.0 \%$ thymine $(\mathrm{T})$, with $\mathrm{A}+\mathrm{T} \%$ slightly larger than $\mathrm{G}+\mathrm{C} \%$. These figures are similar to those reported for other flatfish mitogenomes, as well as the distribution and orientation of protein-coding genes, tRNAs, rRNAs, and the control region (Table 2) (Saitoh et al. 2000, $\mathrm{Xu}$ et al. 2016). However, the sequence similarity of the control regions was low $(1.5 \%$ ), with a length ranging from 1,120 to 2,312 bp (Table 1). In all mitogenomes, the translation initiation codon for protein-coding genes was ATG; the exception was $C O X 1$, for which the translation initiation codon was GTG, in agreement with the other sequences analyzed in this study and those of other 250 fish species (Satoh et al. 2016). Sequence overlaps were also present in the coding genes for ATP8-ATP6, ND4L-ND4, and ND5-ND6, similar to Paralichthys olivaceus and most fish species (Satoh et al. 2016). Paralichthys californicus has complete stop codons (TAA, TAG ) in genes ND1, COX1, ATP8, ND4L, ND5, and $N D 6$, and partial stop codons (TA or T) in genes ND2, COX2, ATP6, COX3, ND3, ND4, and CYTB, similar to P. olivaceus (Saitoh et al. 2000) (Table 2).

The phylogenetic tree built with the mitogenomes of different species of the order Pleuronectiformes (including flatfish) was rooted to Beryx mollis and contains representatives of 2 suborders: Psettodoidei and Pleuronectoidei (Fig. 2). The former includes primitive flatfish in a single family, 1 genus (Psettodes), and 3 living species (according to WoRMS Editorial Board 2020 ). Currently, Pleuronectoidei comprises 14 families with 134 genera and over 7,000 species (Campbell et al. 2014); however, the number of complete mitochondrial genomes for flatfish species available for (http://www.expasy.org) (Artimo et al. 2012) y el ARNt se confirmó con tRNAscan (Lowe y Eddy 1997) y por comparación con otros ARNt. El análisis filogenético se realizó mediante comparaciones con mitogenomas completos de otros peces planos del centro GenBank del NCBI (Tabla 1). El programa MEGA (Kumar et al. 2016) se utilizó para la alineación del mitogenoma utilizando el procedimiento ClustalW (Thompson et al. 1994) con ajustes predeterminados. Se utilizó el programa jModelTest 2 (Guindon y Gascuel 2003, Darriba et al. 2012) para seleccionar el modelo de sustitución de nucleótidos de mejor ajuste mediante el criterio de información de Akaike (AIC) y criterio de información bayesiano (BIC) con la configuración predeterminada. MrBayes 3.2 (Ronquist y Huelsenbeck 2003) se utilizó para estimar las relaciones filogenéticas con el modelo de mejor ajuste: el modelo de evolución General Time Reversible (GTR) con un modelo de sustitución de distribución gamma y una variación de la tasa distribuida gamma entre sitios $(\mathrm{GTR}+\mathrm{G}+\mathrm{I})$, con la simulación Monte Carlo de la cadena de Markov con 20,000 generaciones, 100 frecuencias de muestra y configuraciones predeterminadas. El árbol filogenético se construyó con FigTree V1.4.4 (Rambaut 2018). Se revisaron las bases de datos de FishBase (Froese y Pauly 2019) y WoRMS (WoRMS Editorial Board 2020) para obtener el número de especies de Paralichthys y su distribución geográfica.

\section{RESULTADOS Y DISCUSIÓN}

Después de recortar las regiones de baja calidad y eliminar las lecturas fallidas, el número total restante de lecturas fue $3,243,808$. Se ensamblaron un total de 284,243 cóntigos con un máximo de $16,858 \mathrm{pb}$ y un mínimo de $200 \mathrm{pb}$. El cóntigo más grande $(16,858 \mathrm{pb}$, cobertura $35.82 \mathrm{x}$; número de acceso de GenBank: MT859134) coincidió con el mitogenoma del lenguado de California, que contiene 13 genes codificadores proteínas, 22 ARNt y 2 ARNr (Tabla 2). También se encontró una región de control putativa (bucle D) de 1,168 pb, según lo sugerido por el servidor MitoFish, que también estuvo presente en otros peces planos (Fig. 1, Tabla 2). Las frecuencias de nucleótidos del mitogenoma observadas en $P$. californicus fueron del $27.5 \%$ de adenina (A), el $29.5 \%$ de citosina (C), el $17.0 \%$ de guanina (G) y el $26.0 \%$ de timina $(\mathrm{T})$, con un $\mathrm{A}+\mathrm{T} \%$ ligeramente mayor que el $\mathrm{G}+\mathrm{C} \%$. Estas cifras son similares a las registradas para otros mitogenomas de peces planos, al igual que la distribución y la orientación de genes codificadores de proteínas, ARNt, ARNr y la región de control (Tabla 2) (Saitoh et al. 2000, $\mathrm{Xu}$ et al. 2016). Sin embargo, la similitud de la secuencia de las regiones de control fue baja (1.5\%), con una longitud que varió de 1,120 a 2,312 pb (Tabla 1). En todos los mitogenomas, el codón de inicio de la traducción para los genes codificadores de proteínas fue ATG; la excepción fue COX1, cuyo codón de inicio de traducción fue GTG, de acuerdo con las otras secuencias analizadas en este estudio y las de otras 250 especies de peces (Satoh et al. 2016). También 
Vargas-Peralta et al.: Mitogenome of Paralichthys californicus

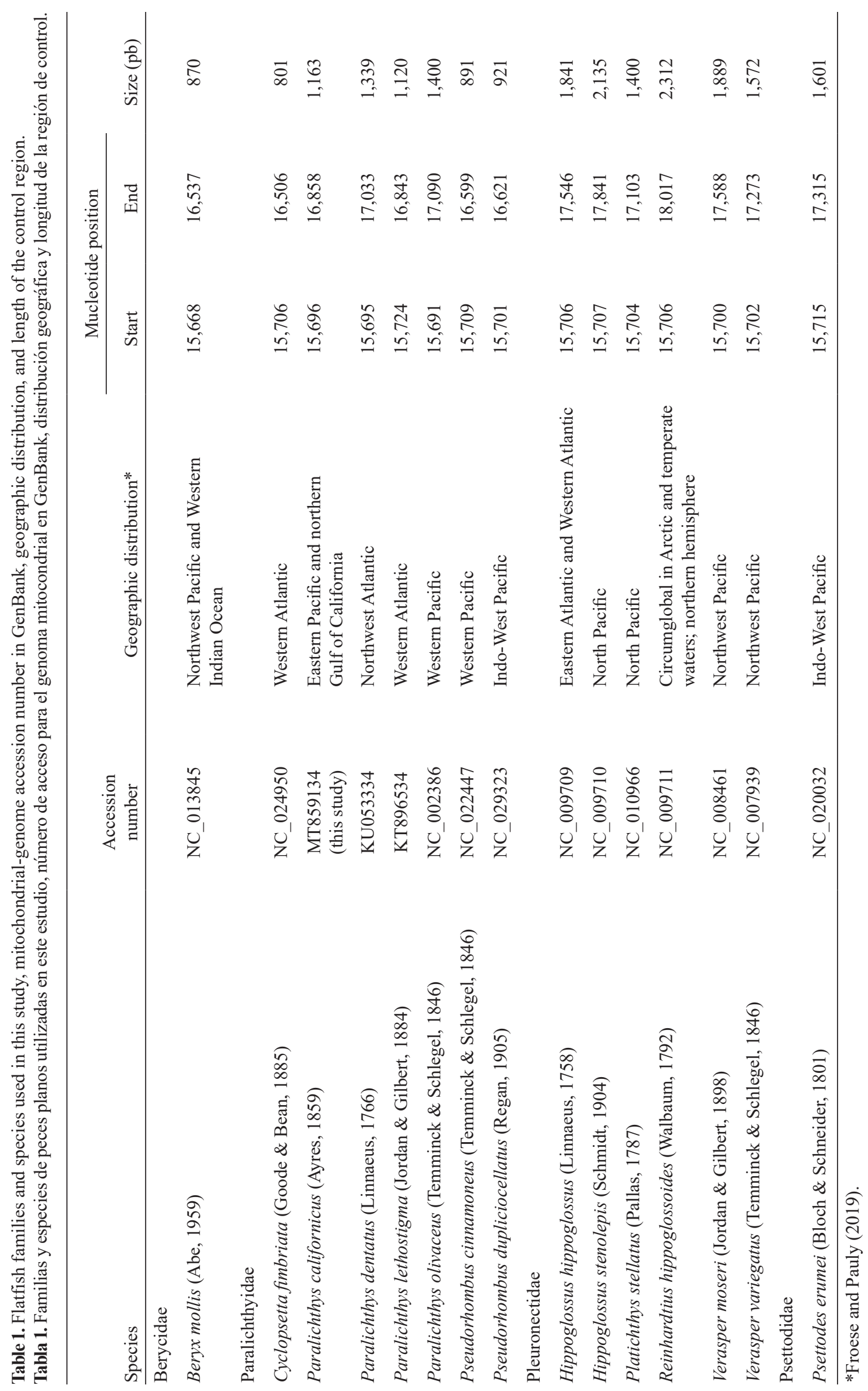


Ciencias Marinas, Vol. 46, No. 4, 2020

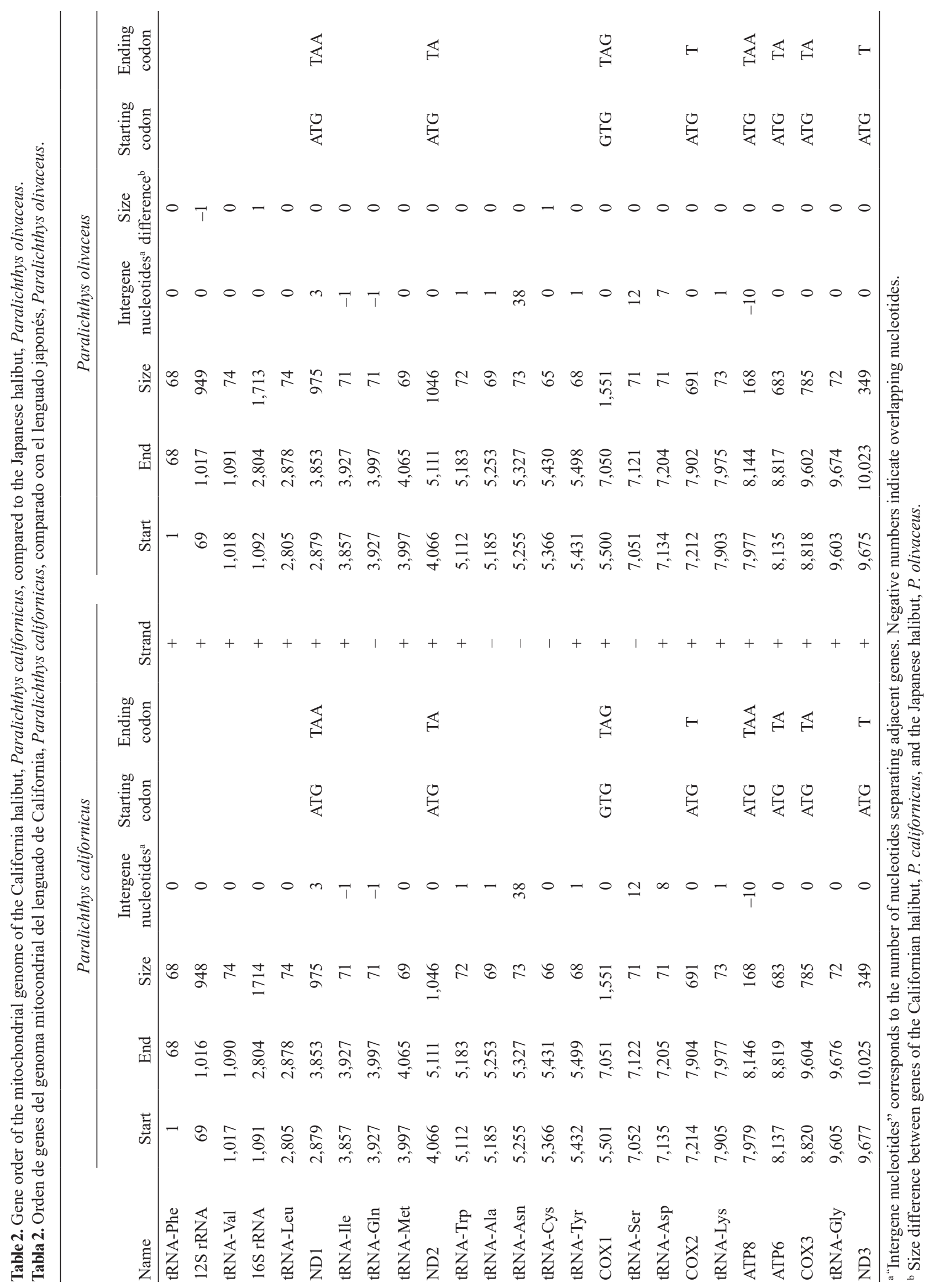




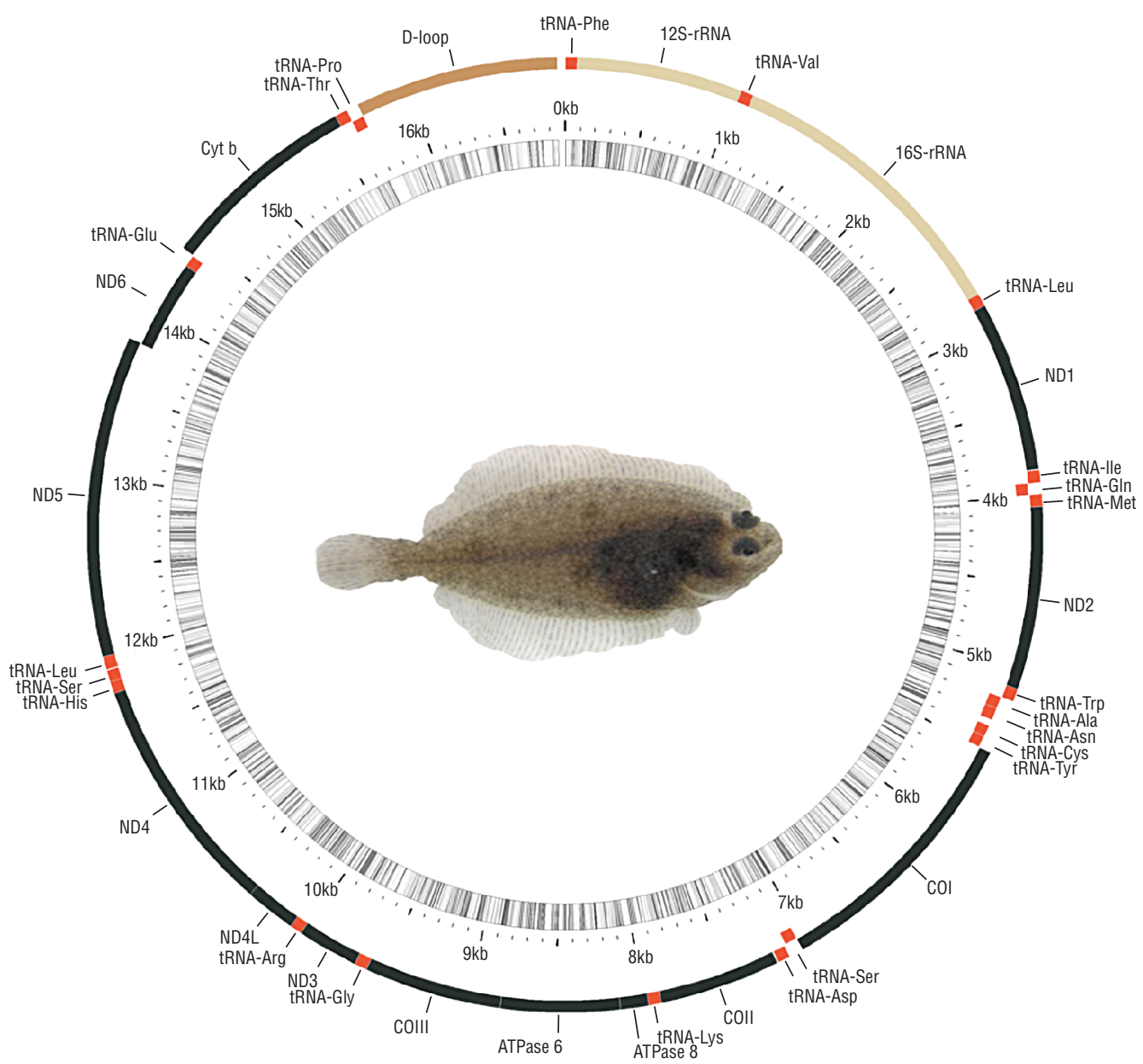

Figure 1. Complete mitochondrial genome of the California halibut, Paralichthys californicus, accession number MT859134.

Figura 1. Genoma mitocondrial completo del lenguado de California, Paralichthys californicus, número de acceso MT859134.

comparison is limited. In the present analysis, we included 11 mitogenomes of Pleuronectoidei species belonging to 2 families: Pleuronectidae and Paralichthyidae. Despite their high sequence similarity in the coding regions, all families were well resolved, as expected (Fig. 2). The mitogenome of the Californian halibut, $P$. californicus, was most similar to that of the Japanese halibut, P. olivaceus, as would be expected given their respective geographic distribution (Table1).

Considering our findings, it can be concluded that the mitogenome of the California halibut, P. californicus, is $16,858 \mathrm{bp}$ in length and contains 13 protein-coding genes, 22 tRNAs, 2 rRNAs, and the control region. The distribution and orientation of protein-coding genes, tRNAs, rRNAs, and the control region of P. californicus were very similar to those in mitogenomes of other flatfish species. The phylogenetic-tree analysis of the families in the order Pleuornectiformes (flatfish) was well resolved. The mitogenome of the California halibut, $P$. californicus, was most similar to that of the Japanese halibut, $P$. olivaceus. Further genetic work on this genus is needed, particularly for $P$. californicus. hubo superposiciones de secuencia en los genes codificadores de ATP8-ATP6, ND4L-ND4 y ND5-ND6, similar a Paralichthys olivaceus y la mayoría de las especies de peces (Satoh et al. 2016). Paralichthys californicus tiene codones finalizadores completos (TAA, TAG) en los genes $N D 1$, $C O X 1, A T P 8, N D 4 L, N D 5$ y ND6, y codones finalizadores parciales (TA o T) en los genes ND2, COX2, ATP6, COX3, ND3, ND4 y CYTB, similar a P. olivaceus (Saitoh et al. 2000) (Table 2).

El árbol filogenético construido con los mitogenomas de diferentes especies del orden Pleuronectiformes (incluido el pez plano) se originó de Beryx mollis y contiene representantes de 2 subórdenes: Psettodoidei y Pleuronectoidei (Fig. 2). El primero incluye peces planos primitivos en una sola familia, 1 género (Psettodes) y 3 especies vivas (según WoRMS Editorial Board 2020). Actualmente, Pleuronectoidei comprende 14 familias con 134 géneros y más de 7,000 especies (Campbell et al. 2014); sin embargo, el número de genomas mitocondriales completos para especies de peces planos disponibles para comparación es limitado. En el presente análisis, incluimos 11 mitogenomas de especies de 


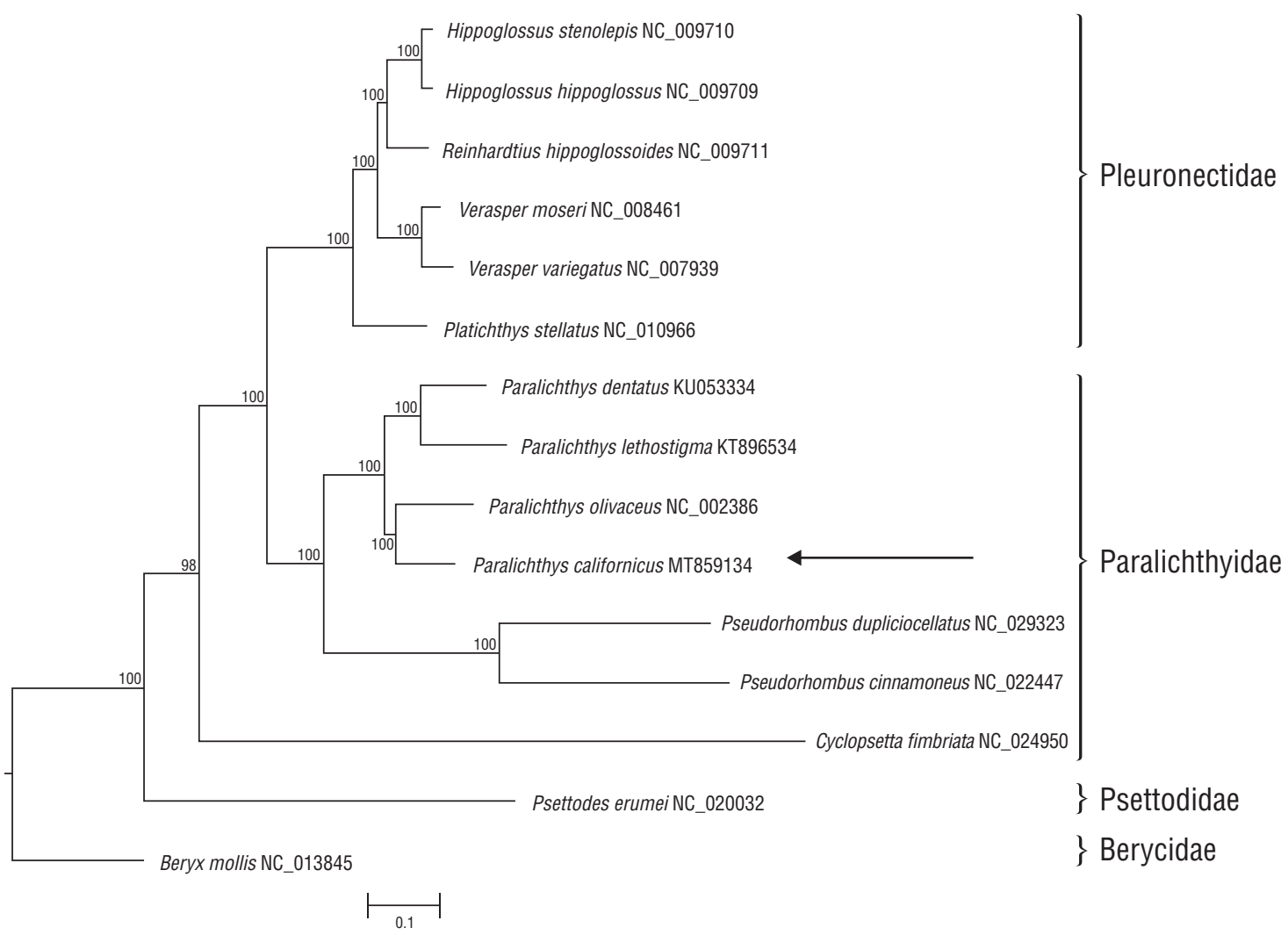

Figure 2. Phylogenetic relationship derived from the best-fit model $(\mathrm{GTR}+\mathrm{G}+\mathrm{I})$ analysis based on complete mitochondrial genomes for three families of Pleuornectiformes (flatfish). Bayesian inference using Beryx mollis as outgroup and root. Arrows points to P. californucus from this study. Node support given as percentage.

Figura 2. Relación filogenética derivada del análisis del modelo de mejor ajuste $(\mathrm{GTR}+\mathrm{G}+\mathrm{I})$ basado en genomas mitocondriales completos para 3 familias de Pleuornectiformes (peces planos). Inferencia bayesiana con Beryx mollis como grupo externo y raíz. Las flechas apuntan al P. californicus de este estudio. Soporte de nodo expresado como porcentaje.

\section{ACKNOWLedgments}

This work was supported by CICESE (project No. 623115, O0C079). María Elena Sánchez-Salazar edited the English version of the manuscript.

\section{REFERENCES}

Artimo P, Jonnalagedda M, Arnold K, Baratin D, Csardi G, de Castro E, Duvaud S, Flegel V, Fortier A, Gasteiger E, et al. 2012. ExPASy: SIB bioinformatics resource portal. Nucleic Acids Res. 40(W1):W597-W603. https://doi.org/10.1093/nar/gks400

Barriga-Sosa I de LA, García De León FJ, Del Río-Portilla MA. 2016. The complete mitochondrial DNA of the endemic shortfin silverside, Chirostoma humboldtianum (Valenciennes, 1835). Mitochondrial DNA Part A. 27(2):1545-1546. https://doi.org/10.3109/19401736.2014.953130

Bernt M, Donath A, Jühling F, Externbrink F, Florentz C, Fritzsch G, Pütz J, Middendorf M, Stadler PF. 2013. MITOS: improved de novo metazoan mitochondrial genome annotation. Mol Phylogenet Evol. 69(2):313-319.

https://doi.org/10.1016/j.ympev.2012.08.023
Pleuronectoidei pertenecientes a 2 familias, Pleuronectidae y Paralichthyidae. A pesar de su alta similitud de secuencia en las regiones codificantes, todas las familias tuvieron buena resolución, como se esperaba (Fig. 2). El mitogenoma del lenguado de California, $P$. californicus, fue muy similar al del lenguado japonés, $P$. olivaceus, como era de esperar dada su respectiva distribución geográfica (Tabla 1).

Tomando en cuenta nuestros hallazgos, se puede concluir que el mitogenoma del lenguado de California, P. californicus, tiene $16,858 \mathrm{pb}$ de longitud y contiene 13 genes codificadores de proteínas, 22 ARNt, 2 ARNr y la región de control. La distribución y orientación de genes codificadores de proteínas, ARNt, ARNr y la región de control de P. californicus fueron muy similares a las de los mitogenomas de otras especies de peces planos. El análisis de árboles filogenéticos de las familias del orden Pleuornectiformes (peces planos) tuvo buena resolución. El mitogenoma del lenguado de California, P. californicus, fue muy similar al del lenguado japonés, $P$. olivaceus. Se necesitan más estudios genéticos sobre este género, particularmente para P. californicus. 
Vargas-Peralta et al.: Mitogenome of Paralichthys californicus

Bisbal-Pardo CI, del Río-Portilla MA, Rocha-Olivares A. 2016a. The complete mitochondrial DNA of the Pacific Geoduck clam (Panopea generosa). Mitochondrial DNA Part A. 27(3):1955-1956.

https://doi.org/10.3109/19401736.2014.971304

Bisbal-Pardo CI, Río-Portilla MA del, Rocha-Olivares A. 2016b. Novel gene arrangement in the mitochondrial genome of the Cortés geoduck clam (Panopea globosa). Mitochondrial DNA Part A. 27(3):1957-1958. https://doi.org/10.3109/19401736.2014.971305

Camacho C, Coulouris G, Avagyan V, Ma N, Papadopoulos J, Bealer K, Madden TL. 2009. BLAST+: architecture and applications. BMC Bioinformatics. 10:421. https://doi.org/10.1186/1471-2105-10-421

Camarena-Rosales F, Del Río-Portilla MA, Ruiz-Campos G, García-De-León FJ. 2016. Entire mitochondrion genome sequence of the desert pupfish, Cyprinodon macularius Baird \& Girard, 1853. Mitochondrial DNA Part A 27:3893-3894. https://doi.org/10.3109/19401736.2014.987251

Campbell MA, López JA, Satoh TP, Chen WJ, Miya M. 2014. Mitochondrial genomic investigation of flatfish monophyly. Gene. 551(2):176-182. https://doi.org/10.1016/j.gene.2014.08.053

Castillo-Páez A, del Río-Portilla MA, Oñate-González E, RochaOlivares A. 2016a. The mitochondrial genome of the banded guitarfish, Zapteryx exasperata (Jordan and Gilbert, 1880), possesses a non-coding duplication remnant region. Mitochondrial DNA Part A. 27(3):1668-1670. https://doi.org/10.3109/19401736.2014.958721

Castillo-Páez A, del Río-Portilla MA, Rocha-Olivares A. 2016b. The complete mitochondrial genome of the giant electric ray, Narcine entemedor (Elasmobranchii: Torpediniformes). Mitochondrial DNA Part A. 27(3):1760-1762. https://doi.org/10.3109/19401736.2014.963800

Chinmayee C, Nischal A, Manjunath CR, Soumya KN. 2018. Next Generation Sequencing in Big Data. Int J Trend Sci Res Dev. 2(4):379-389. https://doi.org/10.31142/ijtsrd12975

Darriba D, Taboada GL, Doallo R, Posada D. 2012. jModelTest 2: more models, new heuristics and parallel computing. Nat Methods. 9:772-772. https://doi.org/10.1038/nmeth.2109

Del Río-Portilla MA, Vargas-Peralta CE, Farfán C, Barriga-Sosa IA, García-de León FJ. 2016a. The complete mitochondrial DNA of the bay snook, Petenia splendida, a native Mexican cichlid. Mitochondrial DNA. 27:1381-1382. https://doi.org/10.3109/19401736.2014.947590

Del Río-Portilla MA, Vargas-Peralta CE, Lafarga-De La Cruz F, Arias-Rodriguez L, Delgado-Vega R, Galván-Tirado C, Garcíade León FJ. 2016b. The complete mitochondrial DNA of the tropical gar (Atractosteus tropicus). Mitochondrial DNA Part A. 27(1):557-558. https://doi.org/10.3109/19401736.2014.905856

Del Río-Portilla MA, Vargas-Peralta CE, Machkour-M'Rabet S, Hénaut Y, García-De Léon FJ. 2016c. Lionfish, Pterois volitans Linnaeus 1758, the complete mitochondrial DNA of an invasive species. Mitochondrial DNA. 27(2):1423-1424. https://doi.org/10.3109/19401736.2014.953075

Del Río-Portilla MA, Vargas-Peralta CE, Paz-García DA, LafargaDe La Cruz F, Balart EF, García-de Léon FJ. 2016d. The complete mitochondrial DNA of endemic Eastern Pacific coral (Porites panamensis). Mitochondrial DNA. 27(1):738-739. https://doi.org/10.3109/19401736.2014.913166

[DOF] Diario Oficial de la Federación. 2007 Jun 5. Área natural protegida, con la categoría de reserva de la biosfera, la zona

\section{Agradecimientos}

Este trabajo fue apoyado por el CICESE (proyecto No. 623115, O0C079). María Elena Sánchez-Salazar editó la versión en inglés del manuscrito.

Traducción al español por Editage.

marina conocida como Bahía de los Angeles, canales de Ballenas y de Salsipuedes. Mexico City: DOF.

[DOF] Diario Oficial de la Federación. 2010 Jul 1. Aviso mediante el cual se informa al público en general que el Consejo Nacional de Áreas Naturales Protegidas, ha emitido opinión favorable para incorporar al Sistema Nacional de Áreas Naturales Protegidas (SINAP), las Áreas Naturales Protegidas de compet. Mexico City: DOF.

[FAO] Food and Agriculture Organization of the United Nations. 2020. FAO FishFinder: Paralichthys olivaceus (Temminck \& Schlegel, 1846). Rome (Italy): FAO Fisheries and Aquaculture Department; accessed 2020 Feb 25.http://www.fao.org/fishery/ species/3350/en

Froese R, Pauly D (eds.). 2019. FishBase. World Wide Web Electronic Publication. [Place unknown]: FishBase; [acessed 2020 Feb 25]. www.fishbase.org.

Galván-Tirado C, del Río-Portilla MA, Delgado-Vega R, GarcíaDe León FJ. 2016. Genetic variability between complete mitochondrion genomes of the sablefish, Anoplopoma fimbria (Pallas, 1814). Mitochondrial DNA Part A. 27(4):2429-2430. https://doi.org/10.3109/19401736.2015.1030628

Glenn TC, Nilsen RA, Kieran TJ, Sanders JG, Bayona-Vásquez NJ, Finger JW, Pierson TW, Bentley KE, Hoffberg SL, Louha S et al. 2019. Adapterama I: universal stubs and primers for 384 unique dual-indexed or 147,456 combinatorially-indexed Illumina libraries (iTru \& iNext). PeerJ. 7:e7755. https://doi.org/10.7717/peerj.7755

Gracian-Negrete J, del Moral-Flores L, Pérez-Ponce De León G. 2015. Diversidad de peces planos en México. Biodiversitas. 121:12-16.

Guindon S, Gascuel O. 2003. A simple, fast, and accurate algorithm to estimate large phylogenies by maximum likelihood. Syst Biol 52(5):696-704. https://doi.org/10.1080/10635150390235520

Iwasaki W, Fukunaga T, Isagozawa R, Yamada K, Maeda Y, Satoh TP, Sado T, Mabuchi K, Takeshima H, Miya M et al. 2013. MitoFish and MitoAnnotator: A mitochondrial genome database of fish with an accurate and automatic annotation pipeline. Mol Biol Evol. 30(11):2531-2540. https://doi.org/10.1093/molbev/mst141

Kumar S, Stecher G, Tamura K. 2016. MEGA7: Molecular Evolutionary Genetics Analysis version 7.0 for bigger datasets. Mol Biol Evol. 33(7):1870-1874.

https://doi.org/10.1093/molbev/msw054

León-Pech MG, Castillo-Páez AY, Bisbal-Pardo CI, RochaOlivares A, del Río-Portilla MA. 2016. Complete mitochondrial genome of the beaubrummel Damselfish, Stegastes flavilatus (Pisces: Perciformes, Pomacentridae). Mitochondrial DNA Part A 27(6):4136-4138. https://doi.org/10.3109/19401736.2014.1003880

Lowe TM, Eddy SR. 1997. tRNAscan-SE: a program for improved detection of transfer RNA genes in genomic sequence. Nucleic Acids Res. 25(5):955-964. https://doi.org/10.1093/nar/25.5.955 
Magallón-Gayón E, del Río-Portilla MÁ, Barriga-Sosa IA. 2020. The complete mitochondrial genomes of two octopods of the eastern Pacific Ocean: Octopus mimus and 'Octopus' fitchi (Cephalopoda: Octopodidae) and their phylogenetic position within Octopoda. Mol Biol Rep. 47:943-952. https://doi.org/10.1007/s11033-019-05186-8

Metzker ML. 2010. Sequencing technologies-the next generation. Nat Rev Genet. 11(11):31-46. https://doi.org/10.1038/nrg2626

Rambaut A. 2018. FigTree v1.4.4. [Place unknown]: [Publisher unknown]; accessed 2020 Feb 25. https://github.com/rambaut/figtree/releases/tag/v1.4.4

Rohland N, Reich D. 2012. Cost-effective, high-throughput DNA sequencing libraries for multiplexed target capture. Genome Res. 22(5):939-946. https://doi.org/10.1101/gr.128124.111

Ronquist F, Huelsenbeck JP. 2003. MrBayes 3: Bayesian phylogenetic inference under mixed models. Bioinformatics. 19(12):1572-1574. https://doi.org/10.1093/bioinformatics/btg180

Saitoh K, Hayashizaki K, Yokoyama Y, et al. 2000. Complete nucleotide sequence of Japanese flounder (Paralichthys olivaceus) mitochondrial genome: structural properties and cue for resolving teleostean relationships. J Hered. 91(4):271-278. https://doi.org/10.1093/jhered/91.4.271

Satoh TP, Miya M, Mabuchi K, Nishida M. 2016. Structure and variation of the mitochondrial genome of fishes. BMC Genomics. 17:719. https://doi.org/10.1186/s12864-016-3054-y
Schuster SC. 2008. Next-generation sequencing transforms today's biology. Nat Methods 5:16-18. https://doi.org/10.1038/nmeth1156

[SEPESCABC] Secretaría de Pesca y Acuacultura de Baja California. 2017. Carta Estatal Pesquera de Baja California. [Place unknown]: Secretaría de Pesca y Acuacultura del Gobierno de Baja California; accessed 2020 Feb 25. 233 p. https://vdocuments.mx/carta-estatal-pesquera-sepescabc. html

Thompson JD, Higgins DG, Gibson TJ. 1994. CLUSTAL W: improving the sensitivity of progressive multiple sequence alignment through sequence weighting, position-specific gap penalties and weight matrix choice. Nucleic Acids Res. 22(22):4673-4680. https://doi.org/10.1093/nar/22.22.4673

WoRMS Editorial Board. 2020. World Register of Marine Species. World Wide Web Electronic Publication. [Place unknown]: [Publisher unknown]; accessed 2020 Aug 10. http://www. marinespecies.org

Wyman SK, Jansen RK, Boore JL. 2004. Automatic annotation of organellar genomes with DOGMA. Bioinformatics. 20(17):3252-3255. https://doi.org/10.1093/bioinformatics/bth352

Xu Y, Liu X, Shi B, Wang B. 2016. Complete mitochondrial genome of summer flounder Paralichthys dentatus (Pleuronectiformes, Paralichthyidae). Mitochondrial DNA Part B Resour. 1(1):889-890. https://doi.org/10.1080/23802359.2016.1258340

Received February 2020, accepted September 2020. 